\title{
HILANGNYA SINERGITAS MASYARAKAT DENGAN SUNGAI DALAM TATA RUANG PERMUKIMAN BANTARAN SUMBER DI SURAKARTA
}

\author{
Tri Hartanto \\ Program Studi Arsitektur, Fakultas Teknik, Universitas Tunas Pembangunan Surakarta (UTP) \\ tri.hartanto23@yahoo.com \\ Rully \\ Program Studi Arsitektur Fakultas Teknik Universitas Tunas Pembangunan Surakarta \\ rullystmt@gmail.com
}

\begin{abstract}
Abstrak
Didalam upaya mencegah meluapnya air sungai pada saat banjir, maka model pembuatan tanggul yang tinggi berupa dinding beton di pinggiran sungai menjadi alternatif yang banyak digunakan. Pembangunan tanggul dinding beton yang tinggi ini secara fungsional mampu mencegah luapan banjir di permukiman bantaran sungai. Namun secara sosial budaya, interaksi yang dimungkinkan terjadi antara manusia dengan sungai menjadi terbatasi, bahkan terkesan tanggul tersebut mengisolasi masyarakat yang ada dalam kawasan permukiman tersebut. Penelitian ini bertujuan untuk menggali makna tanggul sebagai dinding penahan banjir dan pembatas kawasan permukiman bantaran. Penelitian dilakukan menggunakan metode kualitatif dengan melalui observasi lapangan dan wawancara mendalam (indepth interview). Hasil penelitian menunjukkan bahwa keberadaan tanggul secara fungsional mampu mengurangi terjadinya banjir. Di sisi lain tanggul yang dibangun setelah tata ruang permukiman bantaran terbentuk, membatasi dan merubah perilaku masyarakat terhadap sungai. Dimana pada awalnya sungai menjadi inspirasi kehidupan, berubah sungai tidak lagi mendapat perhatian dari masyarakat. sehingga potensi sungai dan kehidupan sosial masyarakat semestinya bisa bersinergi menjadi terputus.
\end{abstract}

Kata kunci: permukiman bantaran, tanggul, tata ruang, surakarta.

\begin{abstract}
In an effort to prevent overflowing of river water during floods, the model of making high embankments in the form of concrete walls on the river bank is a widely used alternative. The construction of high concrete wall embankments is functionally able to prevent flooding in riverbank settlements. However, socially and culturally, the interaction that is possible between humans and rivers is limited, and even the dykes seem to isolate the people in the residential area. This study aims to explore the meaning of the embankment as a retaining wall for flooding and limiting residential areas. The study was conducted using qualitative methods through field observation and indepth interviews. The results showed that the existence of functional dykes can reduce flooding. On the other side of the embankment, which was built after the spatial layout of the riverbanks was formed, limited and changed people's behavior towards the river. Where in the beginning the river became the inspiration of life, it changed the river no longer to get the attention of the community. so that the potential of rivers and the social life of communities should be able to work together to be cut off.
\end{abstract}

Keywords: : settlement area, embankment, spatial planning, Surakarta. 


\section{PENDAHULUAN}

Kota Surakarta memiliki beberapa sungai yang cukup besar di tengah kota, sehingga terbentuk permukiman yang berada di tepian sungai yang dikenal dengan istilah permukiman bantaran. Bantaran sungai adalah ruang antara tepi palung sungai dan kaki tanggul sebelah dalam yang terletak di kiri dan/atau kanan palung sungai (Peraturan Menteri PU no 28 tahun 2015). Area bantaran sungai merupakan area yang tepat berada di tepi sungai dan merupakan area yang tertutup oleh luapan air sungai saat banjir (floodplain). Bantaran sungai memiliki fungsi ekologis sebagai daerah penyangga daerah pengelolaan air dan merupakan jalur koridor hijau. Sebagai daerah penyangga dan jalur koridor hijau daerah bantaran sungai menjembatani keberadaan habitat dan ekosistem darat dengan perairan. Sehingga jika fungsi bantaran sungai terganggu, maka keberadaan habitat dan ekosistem juga akan terganggu. Terganggunya habitat dan ekosistem ini dalam jangka panjang dapat menyebabkan permasalahan lingkungan lain seperti pencemaran air, berkurangnya kemampuan tata kelola air dan iklim mikro (Waryono, 2009).

Menurut Aulawi (2019) fungsi utama dari sungai adalah sebagai penampung air hujan, maka potensi banjir bisa dicegah secara dini. Disamping itu aliran air sungai ini juga bisa dimanfaatkan untuk membangkitkan sumber listrik yang sering dikenal dengan Pembangkit Listrik Tenaga Air (PLTA). Sungai juga berfungsi sebagai pusat ekosistem, khususnya ekosistem berbagai jenis ikan. Jika ikannya terjaga dengan baik, maka bisa menjadi sumber penghasil ikan bagi mereka yang mencari nafkah dari menangkap ikan. Atau menjadi tempat hiburan bagi mereka yang suka memancing ikan di sungai. Ada juga yang memanfaatkan sungai sebagai sarana transportasi perairan dan tentu menjadi ladang penghasilan juga. Selain itu sebagian masyarakat memandang sungai sebagai tempat rekreasi. Banyak orang yang tinggal dan bekerja di perkotaan merasa jenuh dengan rutinitas kerjanya, maka sungai menjadi salah satu alternatif tujuan tempat rekreasi. Sekarang ini sudah banyak sungai yang telah menjadi tujuan wisata, baik di daerah pedesaan maupun perkotaan.

Sempadan sungai atau floodplain terdapat di antara ekosistem sungai dan ekosistem daratan. Berdasarkan Surat Keputusan Presiden Republik Indonesia No.32 Tahun 1990 tentang Pengelolaan Kawasan Lindung, sempadan sungai didefinisikan sebagai kawasan sepanjang kiri dan kanan sungai, termasuk sungai buatan/kanal/saluran irigasi primer, yang mempunyai manfaat penting untuk mempertahankan fungsi sungai. Daerah sempadan mencakup daerah bantaran sungai yaitu bagian dari badan sungai yang hanya tergenang air pada musim hujan dan daerah sempadan yang berada di luar bantaran yaitu daerah yang menampung luapan air sungai di musim hujan dan memiliki kelembaban tanah 
yang lebih tinggi dibandingkan kelembaban tanah pada ekosistem daratan. Banjir di sempadan sungai pada musim hujan adalah peristiwa alamiah yang mempunyai fungsi ekologis penting dalam menjaga keseimbangan lingkungan dan kesuburan tanah (Esty Poedjioetami, 2008).

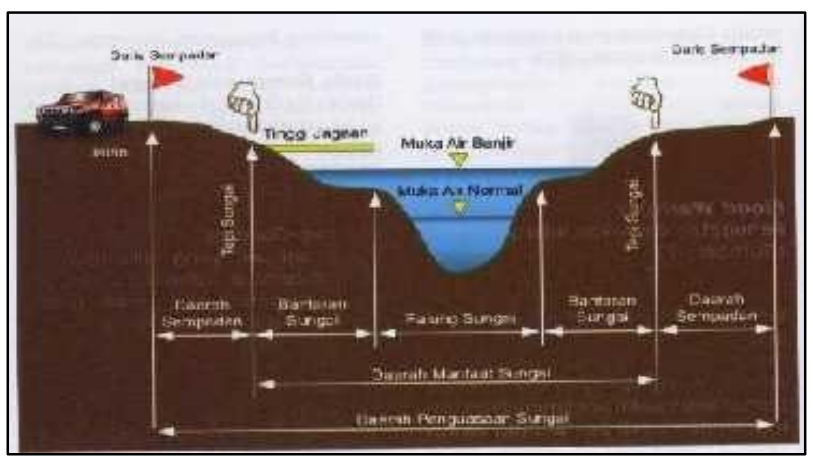

Gambar 1. Diagram Posisi Bantaran Sungai (Sumber : pustaka.pu.go.id)

Keberadaan permukiman di sepanjang bantaran sungai bukan sesuatu yang baru. Kondisi geografis negara Indonesia yang memiliki banyak sungai sebagai orientasi kehidupan menjadikan tepian air/sungai sebagai tempat bermukim dan mencari mata pencaharian (Rahmadi, 2009). Cukup banyak kota-kota di Indonesia yang terbentuk karena keberadaan sungai. Kota Surakarta yang tumbuh dari desa Sala, pada awalnya adalah kota yang ditopang oleh kegiatan perekonomian pelabuhan sungai Semanggi. Dari total 472 kota dan kabupaten, hampir 300 kota dan kabupaten dibangun dekat sumber air, baik berupa danau,daerah aliran sungai (DAS), maupun tepi pantai. Daerah Aliran Sungai (menurut Undangundang No.7 Tahun 2004 tentang SDA) DAS adalah suatu wilayah daratan yang merupakan satu kesatuan dengan sungai dan anak-anak sungainya, yang berfungsi menampung, menyimpan, dan mengalirkan yang berasal dari curah hujan ke danau atau ke laut secara alami, yang batas di darat merupakan pemisah topografis dan batas di laut sampai dengan daerah perairan yang masih terpengaruh aktivitas daratan. Sub DAS adalah bagian dari DAS yang menerima air hujan dan mengalirkannya melalui anak sungai ke sungai uatama. Setiap DAS terbagi habis ke dalam Sub DAS-Sub DAS. Adapun pada sempadan sungai memiliki aturan untuk perlindungan kawasan sungai dan sekitarnya Sungai yang terdapat di kawasan sendiri dengan sempadan 5-10 meter berupa jalur hijau atau jalan inspeksi.

Menurut PP No.38 Tahun 2001 Pasal 9, garis sempadan pada sungai tidak bertanggul didalam kawasan perkotaan yaitu: (a) paling sedikit berjarak 10 meter dari tepi kiri dan kanan palung sungai sepanjang alur sungai dalam hal kedalaman sungai kurang dari atau sama dengan 3 meter; (b) paling sedikit berjarak 15 meter dari tepi kiri dan kanan paling sungai sepanjang alur sungai, dalam hal kedalamam sungai lebih dari 3 meter sampai dengan 20 meter; (c) paling sedikit berjarak 30 meter dari tepi kiri dan kanan paling sungai sepanjang alur sungai, dalam hal kedalaman sungai lebih dari 20 meter. Menurut Tony Karim (2010) pada umumnya masyarakat memandang sungai sebagai tempat buangan. Masyarakat menjadikan sungai sebagai tempat buangan barang-barang yang tidak berguna. Karena itulah maka rumah-rumah penduduk 
pada umumnya letaknya membelakangi sungai.

\section{LOKASI DAN METODE PENELITIAN}

Permukiman Bantaran Sumber berada di Kelurahan Sumber, Kecamatan Banjarsari, Kota Surakarta. Garis coklat tebal pada peta menunjukkan wilayah kelurahan sumber, adapun garis putus-putus biru menunjukkan lokasi dari Permukiman Bantaran Sumber.
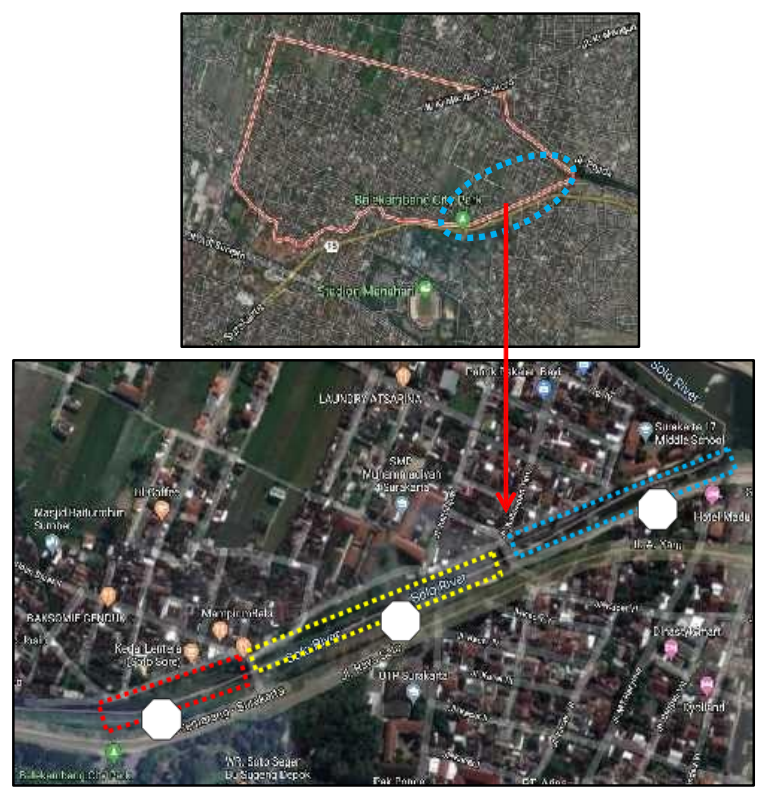

Gambar 2. Lokasi Penelitian dan Segmen Amatan (Sumber: Peneliti, 2019)

Permukiman bantaran ini berbatasan dengan Sungai Gadjah Putih. Sungai Gadjah Putih bermuara pada sungai Kalianyar, sedangkan Sungai Kalianyar bermuara pada Sungai Bengawan Solo. Permukiman ini sangat padat penduduknya. Tata ruang permukiman ini dapat dilihat pola jalan dan pattern hunian yang mengelompok. Pola jalan dapat dilihat dalam Gambar 2. Dimana pola jalan berbentuk grid yang tidak tegak lurus dengan sungai, namun arah jalan menuju sungai.

Sedangkan pola hunian berkelompok hingga tepian sungai. Kondisi permukiman bantaran sungai kampung Sumber saat ini berbeda dengan tempo dulu, dimana tepian sungai dengan permukiman pada waktu dulu tanpa adanya pembatas massif anatara sungai dengan kawasan permukiman. Namun kondisi saat ini antara sungai dan kawasan permukiman terdapat talud dan dinding beton sebagai untuk menahan air sungai saat terjadi banjir besar/sungai meluap.

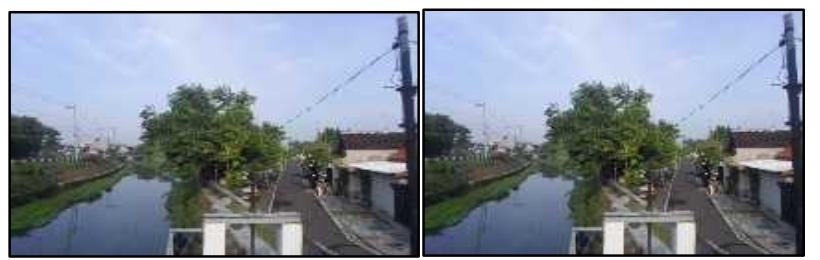

Gambar 3. Suasana Permukiman Bantaran Sungai Kampung Sumber (Sumber: Peneliti, 2019)

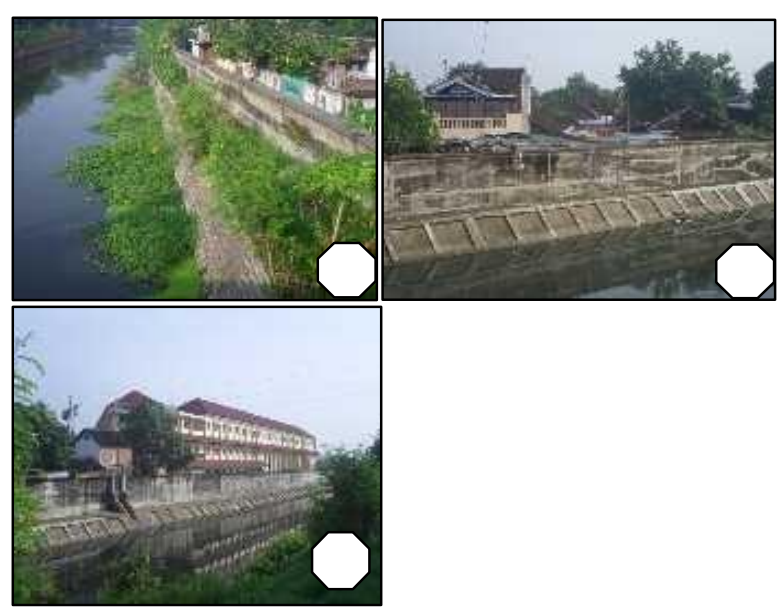

Gambar 4. Talud dan Dinding Beton disepanjang Sungai Gadjah Putih (Sumber: Peneliti, 2019)

Gambar 4 menunjukkan keberadaan talud dan dinding pembatas, antara sungai dan Permukiman Bantaran Sumber. Gambar 4. bagian 1 adalah segmen amatan 1 (garis warna merah), kemudian gambar 4 . bagian 2 adalah segmen amatan 2 (garis warna kuning), sedangkan gambar 4, bagian 3 adalah segmen amatan 3 (garis warna biru), yang dijelaskan 
pada Gambar 2.

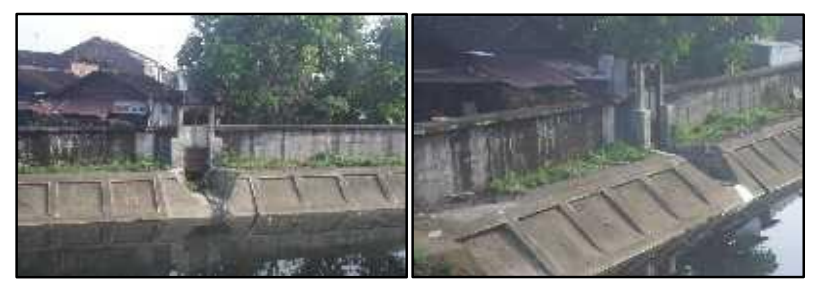

Gambar 5. Saluran Air Kotor Permukiman Masuk Ke Sungai (Sumber: Peneliti, 2019)

Gambar 5. menunjukkan keberadaan saluran air kotor dan air hujan yang berasal dari dalam permukiman, dialirkan ke sungai Gadjah Putih. Untuk menanggulangi luapan air kedalam kawasan permukiman maka pada area buangan dibuat pintu air. Salah satu sinergitas antara tata ruang permukiman dengan sungai. Sinergitas masyarakat dengan sungai dapat dilihat dengan keberdaan tangga bambu, di segmen 2 dan segmen 3 pada Gambar 6 di bawah. Walaupun ditalud dan dinding beton yang cukup tinggi tetapi masyarakat tetap mengupayakan membuat tangga dari bahan material bambu. Tangga bambu ini bisa digunakan untuk akses mincing atau cari ikan.

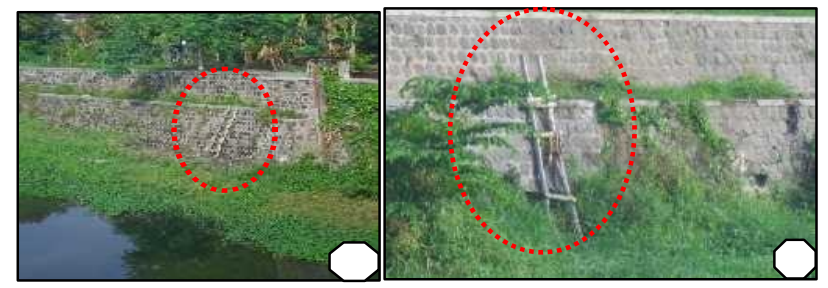

Gambar 6. Diagram Posisi Bantaran Sungai (Sumber: Peneliti, 2019)

Metode yang digunakan untuk penelitian ini adalah metode penelitian kualitatif (Creswell, 2008) yang sifatnya eksploratif (Groat \& Wang, 2002). Penelitian kualitatif eksploratif dipilih karena penulis ingin mendapatkan data-data dengan kemungkinan informasi yang beragam Selain itu, metode ini juga memungkinan penulis untuk menggali secara mendalam (indepth interview) jawaban dari para responden. Peneliti menggali data langsung dari lapangan, data yang bersifat fisik didokumentasikan. Adapun informasi yang dibutuhkan untuk melengkapi data fisik dilakukan wawancara langsung dengan nara sumber (warga masyarakat) permukiman bantaran sungai gadjah Putih. Kemudian berdasarkan data dan informasi, kemudian dianalisis dengan pendekatan teori yang telah dikaji di dalam bab kajian pustaka. Sehingga hasil analisis dapat dinyatakan sebagai hasil dari penelitian.

\section{HASIL DAN PEMBAHASAN}

Dalam Peraturan Pemerintah RI No.38 Tahun 2011 tentang sungai disebutkan bahwa sungai adalah alur atau wadah air alami dan/atau buatan berupa jaringan pengaliran air didalamnya, mulai dari hulu sampai muara, dengan dibatasi kanan dan kiri garis sempadan. Dalam Peraturan Pemerintah RI No.38 Tahun 2011 tentang sungai disebutkan bahwa bantaran sungai adalah ruang antara tepi palung sungai dan kaki tanggul sebelah dalam yang terletak dikiri dan/atau kanan palung sungai. Menurut Binar T. Cesarin dan Chorina Ginting (2015), bahwa permasalahan pada kawasan sungai yang dominan menurut persepsi responden dalam penelitiannya adalah aspek visual dari kawasan. Namun, solusi yang dominan adalah dari aspek lingkungan, diikuti oleh aspek visual, 
perilaku warga dan regulasi. Sehingga dapat disimpulkan bahwa permasalahan visual pada kawasan bantaran sungai sebenarnya dapat diselesaikan melalui solusi terkait dengan lingkungan, visual, perilaku warga serta regulasi.

\section{III.1. Letak Permukiman}

Bantaran

\section{Kampung Sumber}

Berdasarkan kajian pustaka, bahwa permukiman bantaran Kampung Sumber berada pada area bantaran Sungai Gadjah Putih. Dimana permukiman berada di area bantaran sungai sisi utara dari Sungai Gadjah Putih. Sehingga secara regulasi letak permukiman ini tidak sesuai dengan peruntukan sungai sebagai area bantaran sungai. Kondisi ini dapat menyebabkan kemampuan daya tampung air oleh Sungai Gadjah Putih berkurang dan lebih kecil dari daya tampung seharusnya. Sehingga akan mudah terjadi banjir bilamana terjadi hujan dengan kapasitas curah hujan yang tinggi. Berdasarkan amatan di lapangan, selain talud dibangun juga dinding beton di sisi utara sungai, yang melindungi permukiman bantaran ini dari luapan air apabila terjadi banjir. Keberadaan dinding beton yang cukup tinggi ini secara fungsional mampu mencegah luapan air sungai ke area permukiman bantaran Kampung Sumber, namun keberadaannya juga membatasi interaksi masyarakat dengan sungai. Masyarakat terbatasi aksesnya apabila akan memanfaatkan potensi sungai yang cukup banyak bagi masyarakat sekitar. Seperti dalam kajian pustaka, bahwa sungai selain sebagai pengendali banjir, juga dapat dimanfaatkan untuk mencari nafkah dan rekreasi/wisata.

\section{III.2. Tata ruang permukiman}

Memperhatikan pola jalan pada permukiman bantaran Kampung Sumber, maka pola tata permukiman ini berbentuk grid. Tata ruang permukiman di sisi selatan dibatasi oleh dinding beton yang dibangun sepanjang Sungai Gadjah Putih. Jalan utama dalam permukiman ini juga melintasi Sungai Gadjah Putih dengan dibangunnya jembatan. Jembatan ini menghubungkan Kampung Bantaran Sumber yang berada di utara sungai/ berada di sebelah utara jalan raya Solo - Semarang (Jalan Ahmad Yani) dengan wilayah kota Surakarta.

Sebagian besar rumah tinggal menghadap jalan lingkungan, namun jalan lingkungan yang ada berorientasi ke Sungai Gadjah Putih. Hal ini menunjukkan pada jaman dahulu antara permukiman dan sungai terhubung. Masyarakat berinteraksi dengan sungai untuk memenuhi beberapa kebutuhan terkait dengan fungsi sungai. Karena jaman dahulu berdasarkan penjelasan Handoyo (2019), masyarakat menggunakan sungai untuk kebutuhan mandi, mencuci, dan mencari ikan. Namun perkembangan saat ini, dimana kondisi air sungai yang tidak menentu dan adanya pencemaran dari saluran air masyarakat, fungsi sungai sudah berkurang pemanfaatannya oleh warga sekitar.

Kondisi saat ini Sungai Gadjah Putih dengan 
dinding betonnya yang tinggi membentuk tata ruang permukiman bantaran Kampung Sumber menjadi terbatas aksesibilitas. Tata ruang yang semestinya terbuka aksesibilitasnya ke area permukiman sangat terbatas. Sehingga mempengaruhi tingkat kepedulian masyarakat terhadap keberadaan dan kondisi sungai saat ini. Banyaknya tanaman yang tumbuh membentuk pulau di tengah sungai yang menghambat aliran air. Dibuangnya limbah permukiman secara langsung ke sungai berpotensi mencemari air sungai, sehingga mengancam keberlangsungan ekosistem sungai.

\section{III.3. Sinergitas Masyarakat Dengan Sungai}

Hubungan timbal-balik antara masyarakat dan sungai Gadjah Putih pada awalnya terjaga dengan baik, masyarakat memanfaatkan sungai sebagai tempat mencuci, mandi, mencari ikan, dan sekadar melihat pemandangan sungai dan pepohonan di pinggiran sungai, Suryo (2019). Masyarakat juga ikut menjaga sungai, dengan tidak membuang sampah dan kotoran/limbah ke sungai sehingga waktu itu ekosistem sungai terjaga dengan baik. Kondisi saat ini sudah sangat berbeda, dimana kepedulian masyarakat terhadap sungai sangat rendah. Masyarakat sebagian membuang sampah dan limbah ke sungai. Saluran air kotor dari rumah tinggal langsung masuk sungai, dapat dilihat pada gambar 5. Dimana sebaiknya hanya air hujan dan limbah yang sudah diolah yang bisa masuk ke sungai.

Sebenarnya sebagian masyarakat masih

menggunakan sungai untuk kebutuhan seharihari. Hal ini terlihat dari adanya tangga bambu yang dipasang oleh masyarakat sebagai aksesibilitas ke sungai, dapat dilihat pada Gambar 6. Secara alamiah sebenarnya hubungan yang baik antara masyarakat dengan sungai sangat dibutuhkan, sehingga kedua unsure dapat member manfaat kepada keduannya. Kondisi ekosistem sungai akan baik apabila masyarakat sekitar peduli dan menjaga sungai dari sampah dan limbah. Kondisi sungai yang bersih akan memberikan manfaat yang banyak kepada masyarakat, dimana sungai dapat dijadikan obyek wisata maupun untuk sekadar memancing ikan untuk kebutuhan lauk pauk. Sinergitas masyarakat dengan sungai akan dapat berjalan, bilamana tembok dinding beton dirubah dengan tanggul alamiah dari pepohonan yang ditanam di sepanjang talud tanah.

Diperlukannya penataan yang baik tata ruang permukiman bantaran kampung Sumber, yang mengoptimalkan potensi sungai gadjah putih yang mampu mengembalikan fungsi sungai yang sangat beragam kepada masyarakat. Penataan tata ruang mensinergikan sungai dengan area permukiman diwujudkan dengan memberikan aksesibilitas ke sungai sebanyakbanyaknya. Aksesibilitas bisa berupa jalan, jembatan, dan jalur perahu kecil yang mampu memasuki sungai. Perlunya pembongkaran di beberapa titik pada dinding beton, untuk memperluas aksesibiltas masyarakat menuju sungai. 


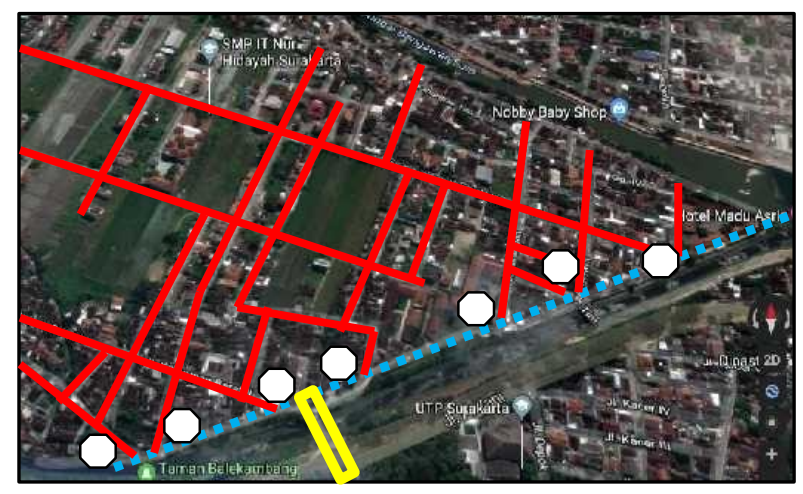

Gambar 7. Tata Ruang Permukiman dengan aksesibilitas menuju sungai (Sumber: Peneliti, 2019)

Gambar 7. menunjukkan Tata Ruang Permukiman Kampung Sumber, dimana pola aksesibilitas permukiman menuju sungai Gadjah Putih. Terdapat 7 (tujuh) titik akses/jalan yang menghubungkan permukiman dengan sungai. Hal ini menunjukkan tata ruang permukiman memiliki hubungan yang erat dengan sungai, interaksi antara masyarakat dengan sungai sangat terlihat. Namun keberadaan tanggul beton yang tinggi (ditunjukkan dengan garis biru putus-putus) menyebabkan putusnya interaksi atau hubungan sungai dangan masyarakat Kampung Sumber. Masyarakat merasa dibatasi, sehingga terbatasi pula interaksi dan peran manusia terhadap sungai didalam menjaga ekosisitem sungai. Kondisi sebaliknya, masyarakat mengalirkan limbah kotor dan sampah ke sungai, menyebabkan air sungai menjadi tercemar.

Kedepan kepedulian masyarakat terhadap sungai diharapkan meningkat sehingga mampu mengembalikan ekoisistem sungai menjadi baik, sehingga sungai dapat dimanfaatkan sebagai wahana wisata yang menyatu dengan permukiman bantaran Kampung Sumber.
Kondisi sekarang ini, dibagian hilir sungai gadjah putih sudah ditata untuk mengembalikan salah satu fungsi sungai, salah satunya yaitu untuk kebutuhan wisata air, seperti pada Gambar 8. Air yang jernih diharapkan mampu menjaga ekosistem sungai, dan kejernihan air sungai senantiasa akan terjaga.
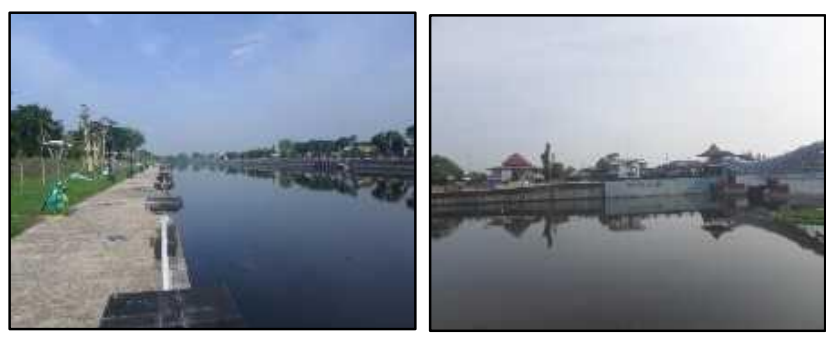

Gambar 8. Kondisi Sungai Kalianyar Yang Merupakan Hilir Dari Sungai Gadjah Putih (Sumber: Peneliti, 2019)

\section{KESIMPULAN}

Hasil penelitian menunjukkan bahwa keberadaan tanggul di permukiman bantaran Kampung Sumber secara fungsional mampu menanggulangi luapan air dan terjadinya banjir. Di sisi lain tanggul yang dibangun setelah tata ruang permukiman bantaran terbentuk, membatasi dan merubah perilaku masyarakat terhadap sungai. Dimana pada awalnya sungai menjadi inspirasi kehidupan, berubah sungai tidak lagi mendapat perhatian dari masyarakat. sehingga potensi sungai dan kehidupan sosial masyarakat semestinya bisa bersinergi menjadi terputus.

Keberadaan sungai dengan berbagai macam potensinya, saat ini mendapat perhatian dari berbagai pihak, baik individu, masyarakat, swasta, maupun dinas-dinas pemerintah. Banyak sungai diperkotaan saat ini dimanfaatkan 
untuk obyek pariwisata, yang bermanfaat bagi masyarakat dan pemerintahan daerah untuk meningkatkan Pendapatan Asli Daerah (PAD) dari sektor wisata, dan pengolahan air sungai sebagai air minum. Pengelolaan potensi sungai semestinya tidak mengabaikan masyarakat yang berada di sekitar bantaran. Selain sebagai aktor penjaga sungai sehingga ekosistem terjaga, masyarakat setempat juga akan bisa ikut mmenikmati indahnya pesona wisata air di sekitar tempat tinggalnya.

\section{DAFTAR PUSTAKA}

Cesarin, B.T dan Ginting Chorina, 2015. Persepsi Masyarakat terhadap Permukiman Bantaran

Sungai, Temu Ilmiah IPLBI 2015

Janny, Chalsie, 2013. Identifikasi Pemanfaatan Ruang Pada Kawasan Permukiman Bantaran

Sungai Di Kelurahan Pakowa Manado. Skripsi.Program Studi Perencanaan Wilayah

\&Kota, Universitas Sam Ratulangi, Manado.

Karim, Tony, 2010. Pengaruh Penataan Bantaran Sungai Bau-Bau Terhadap Pola Hunian Masyarakat Di Kelurahan Tomba Dan Bataraguru Kota Bau-Bau, Tesis Program Pasca Sarjana, Universitas Diponegoro. Semarang.

Mokodongan, B.K. Rieneke L.E. \& Karongkong, H.H, 2014. Identifikasi Pemanfaatan Kawasan

Bantaran Sungai Dayanan Di Kotamobagu, Sabua Vol.6, No.3:273-283 November 2014. Nugroho, Iwan dan Dahuri, Rokhmin. 2012. Pembangunan Wilayah. Jakarta :Alumni.

Peraturan Pemerintah RI No.38 Tahun 2011 Tentang Sungai

SK. Keppres Republik Indonesia No.32 Tahun 1990 tentang Pengelolaan Kawasan Lindung
Peraturan Menteri PU no 28 tahun 2015, tentang Area Bantaran Sungai

Pontoh, Nia K. Setiawan, Iwan, 2008. Pengantar Perencanaan Kota. Bandung, Penerbit ITB. Poedjioetami, Esty, 2008. Penataan Ulang Kawasan Bantaran Sungai Dengan Mengahdirkan

Sentra Ekonomi Dan Rekreasi Kota. Institut Teknologi Adhi Tama. Surabaya. 